\title{
Online Education in HEIs in Bangladesh moderated by COVID-19: Modified UTAUT2
}

\author{
Manzur Hossain Khan, Nurakmal Ahmad Mustaffa and Md. Mamun Habib
}

\begin{abstract}
The whole world, including Bangladesh is brought to a standstill by the pandemic of COVID-19. The HEIs in Bangladesh also struggled to react to this sudden catastrophe; magnified by uncertainties. Compared to public universities, the private universities of the country managed to react the fastest and adopted sweeping changes in a very short period of time, shifting traditional face-toface course content/teaching to online content/teaching. The shift to fully functional online teaching learning platform was sudden and with minimum preparation. To investigate the perception of the private university student community in Bangladesh towards this new teaching-learning method, this paper adopted the Unified Theory of Acceptance and Use of Technology (UTAUT) model, focusing on stakeholders' behavioral intention, availability of the online platform ad resources, prior experience, attitude towards usage and most importantly the impact of COVID-19 pandemic. Additionally, the paper also discusses the issues of social and cultural impact. It was found that all the UTAUT attributes are positively correlated with the Behavioral Intention, and which also positively correlate with students' Use Behavior in adopting online education. The impact of unexpected, and unprecedented COVID-19 pandemic also significantly moderated their behavioral intention towards accepting online education.
\end{abstract}

Index Terms - COVID-19 disease, pandemic impact, Online education, UTAUT2, HEIs Bangladesh

\section{INTRODUCTION}

Currently the higher education (HE) situation in Bangladesh is at a crossroad. The prime issues are concentrated around quality assurance and accreditation that is essential to mark its footstep in the global knowledge economy, and coping with the skillset demands of the employers, in the transitioning dynamic economy of the country - from traditional Agri-based industry to service-oriented. At the same time, higher education institutions (HEIs) are also facing the urgent need to break the shackles of traditional uni-directional classroom-based teaching to adopt modern teaching, learning and assessment techniques to promote higher-level cognitive and soft skills.

Manzur Hossain Khan is a PhD student at the School of Quantitative Sciences, Universiti Utara Malaysia, Malaysia, email: manzur@aiub.edu

Nurakmal Ahmad Mustaffa is a Senior Lecturer of the School of Quantitative Sciences, Universiti Utara Malaysia, Malaysia . email: nurakmal@uum.edu.my

Md. Mamun Habib is a Professor of the School of Business, Independent University, Bangladesh, email: nurakmal@uum.edu.my
And then there is the lack of flexibility towards changes from the society and governing bodies. It is imperative that educational institutes are more vulnerable for the spreading the COVID19 virus. A major part of a student's daily life is spent in close proximity, inside the 4-walls of classrooms or in communal settings. This unprecedented situation not only unsettled our lives but also cause us to evolve towards a paradigm shift, particularly in the Higher Education Institutions (HEI). Stakeholders of the HEIs will need to rethink and reinvent their operating procedures. This virus may be proven to be a catalyst for online education and other relevant digitization of education technologies. One of the most essential new norms is social distancing, which will lead HEIs to adopt distributed structure and develop relevant administrative and pedagogical tools.

\section{A. Convention of Online Classes in Bangladesh due to COVID-19}

Alongside the whole world, Bangladesh is brought to a standstill by the pandemic of COVID-19. All the hustlingbustling of a densely populated country has come to a quiescent halt; the only sound remaining is the whisper of anxiety. The HEIs struggled to react to this sudden catastrophe; magnified by uncertainties. Since March 17, 2020, educational institutes in Bangladesh are closed due to COVID-19 pandemic. Few educational institutes with existing digital infrastructure managed to convert their operations into online platform within the first week. But a good number of educational institutes suffered even after a month of closure. After about two weeks, out of 151 public and private universities of the country, only 63 managed to start online classes [1], only 2 public and 61 private universities. However, the extensibility and effectivity of online classes could not be assessed against the digital readiness of Bangladesh. Bangladesh ranked 105 out of 134 countries in the Network Readiness Index of 2020, and only 5.6 percent had a computer and 37.6 percent had access to the internet at home as per the Bangladesh Bureau of Statistics in 2019 [2].

Classes are shifted online, keeping students and teachers in a safe distance while undertaking their classes. Private universities of the country are accessing online platforms, 
Zoom, Microsoft Teams, Google Classroom, WhatsApp, Facebook, Google Hangout, etc. utilizing to their maximum capacity for online class lectures, assessments, and team-based work projects. Teachers are delivering video lectures while students are communicating through video, audio or messages for their queries, class participation and clarifications, as appropriate and required [3], [4].

This study focuses on the acceptance of online education from the most important stakeholders of HEIs - students. The study also explores the impact of unexpected and unprecedented influence of COVID-19 pandemic on the students' behavioral intention toward ultimate use behavior of online education.

\section{B. Research Objectives:}

1) To analyze the influence and correlation of the attributes on students' behavioral intention towards online education in the HEIs in Bangladesh.

2) To explore the impact of COVID-19 pandemic on the correlation between students' behavioral intention with user behavior towards online education in the HEIs in Bangladesh.

\section{LITERATURE REVIEW}

Numerous researchers studied UTAUT based technology acceptance model in the Higher Education Domain. In majority of the studies the attributes were found positively correlated to the behavioral intention and use behavior of the stakeholders [5]. Lately a good number of studies have been already conducted or still on-going that explore the impact of COVID19 pandemic on academia - globally and also in Bangladesh. [6] conducted a study that included one of the largest number of stakeholders - about 1500 students of the biggest public US universities to study the causal impact of COVID-19 pandemic. The study observed numerous negative effects on many aspects, like, delayed graduation, loss of job, internship, etc. Some of these negative impacts were heterogenous in nature divided into socioeconomic divide, like, 55\% students from lower-income group may be delayed with their graduation than the higherincome group [6]. [7] in their study observed that some specific discipline of study is not suitable trough online platform from students' point of view and majority of the students were demotivated [7]. Resonating with the study of [6], study of [8] explored descriptive statistics to find the perception of educators about online education, and problems faced related to e-learning and revealed that low and lower middle-income groups students have been hit the most [8]. [2] reported about $57 \%$ reported a loss of income since pandemic started distributed as $30 \%$ in the high-income group and $73 \%$ per cent for the low-income. A radical unprecedented shift to online education may be a beginning of a new format of concealed digital divide [2].
Even though many studies were conducted on the online education platform, and COVID-19 impact on the Higher Education Institutes (HEIs) in Bangladesh, but very few were conducted on the technology acceptance model framework. On the way to be a developing country from a least developed country, Bangladesh is yet to adopt digitization in the educational institutes widely [2], [9]. There is certainly a need of study conducted from the users' behavioral intention and use behavior point of view. Moreover, studies on COVID-19 pandemic impact on the users' behavioral intention to adopt online education in HEI context of Bangladesh is also absent. This study aims to fill that gap.

\section{A. Unified Theory of Acceptance and Use of Technology (UTAUT2)}

In 2003, Venkatesh, et. al. established a model named Unified Theory of Acceptance and Use of Technology (UTAUT) to assess the technology acceptance by stakeholders. The model was a combination of Theory of Planned Behavior (TPB), Technology Acceptance Model (TAM), Innovation of Diffusion Theory (IDT), Social Cognitive Theory (SCT) and some more previous research models [10]. Later in 2012, they upgraded the UTAUT model as UTAUT2 addressing some previous limitations and introducing three new attributes named price value, hedonic motivation, and habit [11]. Since then, UTAUT2 has been adopted by numerous researchers to study acceptance and adoption of technology in various fields [12].

In a separate study to identify the determinants relevant to acceptance of IT innovation and use behavior, [13] integrated UTAUT and Entrepreneurial Potential Model, where Precipitating Events was used as a construct which modifies the stakeholders' behavioral intention towards its effect on their final use behavior. Precipitating Event is described as an externally originating incident that influences or hinders user's intention towards its conversion to behavior. In the studies conducted by [14] and [13], researchers suggested that external and environmental factors, and unforeseen events can change users' behavioral intention towards use behavior [15].

In this this study a combination of the above-mentioned concepts - UTAUT2 and Entrepreneurial Model has been adopted and the following conceptual research framework is used: 


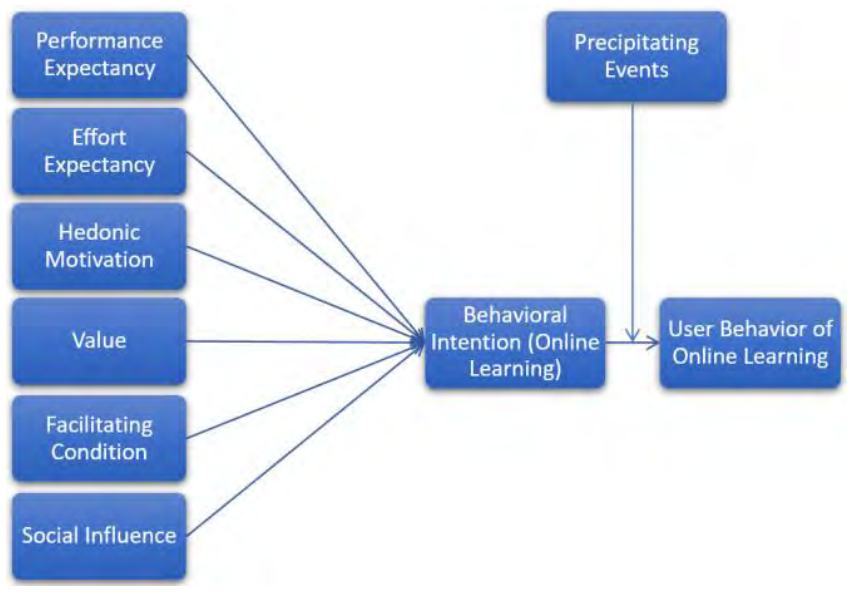

Fig. 1: Conceptual Framework

The UTAUT2 is used to explore the relationship between the constructs as follow:

Performance Expectancy (PE): The level of individual's belief that using technology will help to get the job done [11].

Effort Expectancy (EE): The degree of ease associated with the use of technology [5].

Social Influence (SI): The degree of individual's perception of importance given to the opinions of others that he or she should use technology [11].

Facilitating Conditions (FC): Consumers' perception of the help and resources available for the use of technology [12].

Hedonic Motivation (HM): The pleasure and satisfying experience of using technology [11].

Value (V): The perceived cost of the resources spent, and value gained from using the technology [11].

Behavioral Intention (BI): Indicates how firmly an individual is ready to try or how much effort an individual intends to exert to perform a given act [5].

Precipitating Events (PEV): Uncertain external event or unexpected change in environment that influences individual's decision to adopt new technology [13], [15].

Majority of studies conducted using UTAUT2 model to explore the technology adoption in numerous domain and countries of educational institutes in different settings, found positive correlation among the constructs of UTAUT with the stakeholders' use behavior [5]. Considering the findings of those studies and current pandemic condition, this study is designed with the following hypothesis in alignment of the research objectives:

$\mathrm{H}_{1.1}$ : Performance expectancy has a significant effect on the behavioral intention of students to attend online classes.

$\mathrm{H}_{1.2}$ : Effort expectancy has a significant effect on the behavioral intention of students to attend online classes.

$\mathrm{H}_{1.3}$ : Social influence has a significant effect on the behavioral intention of students to attend online classes.
$\mathrm{H}_{1.4}$ : Facilitating conditions have a significant effect on the behavioral intention of students to attend online classes.

$\mathrm{H}_{1.5}$ : Hedonic motivation has a significant effect on the behavioral intention of students to attend online classes.

$\mathrm{H}_{1.6}$ : Value has a significant effect on the behavioral intention of students to attend online classes.

$\mathrm{H}_{2}$ : Precipitating Event moderated the behavioral intention of students to attend online classes.

A similar research was conducted by [16] to investigate factors that influence Jordanian students' behavioral intention to use elearning using the extended Technology Acceptance Model (TAM). [16] study included 4 constructs of the model and subject norm to represent COVID-19 impact. It also confirmed the positive effect of the variable on students' e-learning intention with the effect of COVID-19 impact. But the definitional of 'Precipitating Event' given by $[13,15]$ is more appropriate in characterizing the impact of COVID-19 along with the constructs of UTAUT2 model.

\section{METHODOLOGY}

This study was conducted qualitatively and quantitatively, involving five different phases of the research process. Phase 1 involved the process of reviewing literature related to UTAUT2 and the application of Online Learning in HEIs, covering the topic of criteria or elements needed for online class, characteristics of lecturers when teaching online class and technique used in examining the structural path modelling. A semi-structured interview has also been conducted with three educators who are experts in online class teaching and learning and have teaching experience of more than seven years in HEIs. This interview serves the purpose of seeking more information on the scenario of online class during the COVID-19 pandemic.

Based on the information gathered in Phase 1, a conceptual framework is developed and has been clarified with explanation of FIGURE 1. In Phase 2, to test the significance of correlation, the hypotheses (H1.1 - H.16) of the relationships among the variables were outlined in Phase 2, which statistically tested the significance effect on Behavioral Intention (BI) of the structural paths between '6 Constructs' (i.e. PE, EE, SI, FC, VL, and $\mathrm{HM})$. And to test the significance of the moderation model, the hypothesis (H2) on the influence of Precipitating Event (PEV) in term of its moderation on the relationships among the Behavioral Intention (BI) and Use Behavior (UB) is statistically tested.

In Phase 3, this study used a questionnaire as a tool to collect the data for model testing. The constructed questionnaire consists of three main parts. The first part of the questionnaire collected the data related to demographics and 29 items of statement constructed for the sections of the students' behavioral intention toward technology adoption and how precipitating events modifies the behavioral intention towards the actual use behavior. The degree of respondents' agreement 
with the items in second and third sections were measured with the Likert scale of 7-points, ranging from 'Strongly Agree' to 'Strongly Disagree'. The pilot test was conducted to examine the quality of the questionnaire using the content validity and the reliability test. The content validity refers to the agreement of the expert whether the items of the question constructed related to the variables identified in second part. The experts were the educators who are actively involved in projects related to the online class or online-based learning. Based on the expert opinion, the wordings in the questionnaire were revisited and few of the items were restructured according to its applicability to the variables in the research framework. Meanwhile, for the reliability test, a data survey using the questionnaire developed collected from a total of randomly selected 29 respondents. The result of the Cronbach's Alpha among all items of all the variable showed a value of 0.960 among the sum of variables is 0.93, which proved that all the items used in these cases have relatively high internal consistency. Detail results of Cronbach's Alpha for each variable in the model are tabulated in TABLE I and II.

Then, the data were collected once the questionnaire was ready in Phase 4. An online survey was conducted at the end of the Fall 2020-21 semester at the American International University-Bangladesh (AIUB), Bangladesh extracting 192 valid responses from 200 respondents who voluntarily answered the questions. For 29 items, as per sample-to-item ratio, more than 150 respondents (5-to-1) is sufficient [19].

Some of the important and interesting demographic (social and cultural) observations are - majority students (37\%) belong to the family with monthly income range of $25000-50000$ BDT, majority students (40\%) uses internet for 3- 5 hours daily. Even though majority students indicated their first preference of using internet is for Education, but majority students (37\%) spend 3 - 5 hours daily on social media, very interestingly $48 \%$ (highest) female students are in this same bracket. In metropolitan city, majority of their internet connectivity is broadband; but in rural areas most of them depend on mobile data (Appendix A).

Once the data was clean and without any missing value, the statistical analysis was deployed to analyze the data. First, descriptive analyses were conducted to describe the background of the respondents and the profile of internet usage among the respondents. Pearson's correlation (r) method was adopted to measure the correlation among the variables. The value of $r$ may be from -1 to +1 ; where greater than 0 indicates positive relationship, 0 means no relationship, and less than 0 indicates negative relationship [20]. Regression-based Moderation Analysis was conducted to measure the moderation effect of precipitating events (COVID-19 pandemic) on the relationship between behavioral intention and use behavior. The PROCESS 3.5 plugin in SPSS developed by Andrew F. Hayes was used for this purpose. The moderation analysis was interpreted based on the reference values and the equation given below [17], [18]:

- The probability value ' $p$ ' of interaction of moderator and independent variables is significant if it is less than 0.05 .

- If there are variations in the graphs plotted with low, medium and high moderator value with the independent and dependent variables.

$$
\hat{Y}=b_{0}+b_{1} X+b_{2} W+b_{3} X W
$$

\section{RESULTS AND DisCUSSIONS}

\section{A. Reliability Analysis:}

TABLE I

RELIABILITY STATISTICS

\begin{tabular}{|l|l|l|l|}
\hline \multicolumn{2}{|l|}{$\begin{array}{l}\text { Among all Items of all the } \\
\text { variable }\end{array}$} & \multicolumn{2}{l|}{ Among the Sum of Variables } \\
\hline $\begin{array}{l}\text { Cronbach's } \\
\text { Alpha }\end{array}$ & $\begin{array}{l}\text { N of } \\
\text { Items }\end{array}$ & $\begin{array}{l}\text { Cronbach's } \\
\text { Alpha }\end{array}$ & $\begin{array}{l}\text { N of } \\
\text { Items }\end{array}$ \\
\hline .960 & 29 & .930 & 9 \\
\hline
\end{tabular}

TABLE II

RELIABILITY AMONG THE INDIVIDUAL ITEMS IN EACH VARIABLE

\begin{tabular}{|l|l|l|}
\hline \multicolumn{1}{|c|}{ Variables } & $\begin{array}{l}\text { Cronbach's } \\
\text { Alpha }\end{array}$ & $\begin{array}{l}\text { No. of } \\
\text { items }\end{array}$ \\
\hline Performance Expectancy (PE) & 0.868 & 4 \\
\hline Effort Expectancy (EE) & 0.821 & 3 \\
\hline Social Influence (SI) & 0.788 & 4 \\
\hline Facilitating Conditions (FC) & 0.712 & 3 \\
\hline Value (VL) & 0.788 & 3 \\
\hline Hedonic Motivation (HM) & 0.907 & 3 \\
\hline Precipitating events (PEV) & 0.860 & 3 \\
\hline Behavioral Intention (BI) & 0.892 & 3 \\
\hline Use Behavior (UB) & 0.772 & 3 \\
\hline
\end{tabular}

Cronbach's alpha was measured in more than one way to measure the reliability of data. Cronbach's alpha is calculated to measure the internal consistency of the items to find out how closely they are related to each other as a group. The value of Cronbach's alpha ranges from 0 to 1 . Expected reliability of items is based on their Cronbach's alpha value of 0.6 or more [20].

All the items of the variable were found reliable with minimum Cronbach's Alpha value of 0.712. (Table I and II).

\section{B. Correlation Analysis:}

TABLE III

CORRELATION (PEARSON's) ANALYSIS AMONG THE ATTRIBUTES

\begin{tabular}{|l|l|l|l|l|}
\hline & BI1 & BI2 & BI3 & \multirow{2}{*}{ BI (Sum) } \\
\hline PE1 & $.606^{* *}$ & $.589^{* *}$ & $.630^{* *}$ & $.698^{* *}$ \\
\cline { 1 - 4 } PE2 & $.578^{* *}$ & $.564^{* *}$ & $.595^{* *}$ & \\
\cline { 1 - 3 } PE3 & $.498^{* *}$ & $.536^{* *}$ & $.597^{* *}$ & \\
\cline { 1 - 3 } PE4 & $.422^{* *}$ & $.367^{* *}$ & $.451^{* *}$ & \\
\hline
\end{tabular}




\begin{tabular}{|c|c|c|c|c|}
\hline EE1 & $.346^{* *}$ & $.409^{* *}$ & $.411^{* *}$ & \multirow[t]{3}{*}{$.617^{* *}$} \\
\hline EE2 & $.527^{* *}$ & $.487^{* *}$ & $.514^{* *}$ & \\
\hline EE3 & $.513^{* *}$ & $.546^{* *}$ & $.559^{* *}$ & \\
\hline SI1 & $.563^{* *}$ & $.502^{* *}$ & $.549^{* *}$ & \multirow{4}{*}{$.695^{* *}$} \\
\hline SI2 & $.445^{* *}$ & $.479^{* *}$ & $.491^{* *}$ & \\
\hline SI3 & $.495^{* *}$ & $.405^{* *}$ & $.456^{* *}$ & \\
\hline SI4 & $.461^{* *}$ & $.526^{* *}$ & $.542^{* *}$ & \\
\hline FC1 & $.370^{* *}$ & $.369^{* *}$ & $.351^{* *}$ & \multirow{3}{*}{$.493^{* *}$} \\
\hline FC2 & $.345^{* *}$ & $.362^{* *}$ & $.284^{* *}$ & \\
\hline FC3 & $.384^{* *}$ & $.385^{* *}$ & $.354^{* *}$ & \\
\hline VL1 & $.541^{* *}$ & $.463^{* *}$ & $.406^{* *}$ & \multirow[t]{3}{*}{$.623^{* *}$} \\
\hline VL2 & $.435^{* *}$ & $.494^{* *}$ & $.527^{* *}$ & \\
\hline VL3 & $.453^{* *}$ & $.455^{* *}$ & $.491^{* *}$ & \\
\hline HM1 & $.498^{* *}$ & $.518^{* *}$ & $.581^{* *}$ & \multirow[t]{3}{*}{$.708^{* *}$} \\
\hline HM2 & $.598^{* *}$ & $.633^{* *}$ & $.644^{* *}$ & \\
\hline HM3 & $.598^{* *}$ & $.600^{* *}$ & $.641^{* *}$ & \\
\hline
\end{tabular}

TABLE IV

CORRELATION (PEARSON'S) OF BEHAVIORAL INTENTION (BI) AND PRECIPITATING EVENTS WITH USE BEHAVIOR OF ONLINE LEARNING

\begin{tabular}{|c|c|c|c|c|}
\hline & UB1 & UB2 & UB3 & UB (SUM) \\
\hline PEV1 & $.241^{* *}$ & $.184^{*}$ & $.296^{* *}$ & \multirow[t]{3}{*}{$.375^{* *}$} \\
\hline PEV2 & $.344^{* *}$ & $.240^{* *}$ & $.285^{* *}$ & \\
\hline PEV3 & $.385^{* *}$ & $.195^{*}$ & $.297^{* *}$ & \\
\hline BI1 & $.741^{* *}$ & $.474^{* *}$ & $.610^{* *}$ & \multirow[t]{3}{*}{$.843^{* *}$} \\
\hline BI2 & $1.000^{* *}$ & $.444^{* *}$ & $.627^{* *}$ & \\
\hline BI3 & $.782^{* *}$ & $.426^{* *}$ & $.594^{* *}$ & \\
\hline
\end{tabular}

**. Correlation is significant at the 0.01 level (2-tailed).

*. Correlation is significant at the 0.05 level (2-tailed).

Correlations (Pearson's correlation) value of all the attributes- Performance Expectancy (PE), Effort Expectancy (EE), Social Influence (SI), Facilitating Conditions (FC), Hedonic Motivation (HM), Value (V) are found positive (Table III). Precipitating Events (PEV) and Behavioral Intention (BI) are also positively correlated to Use Behavior (UB) (Table IV); Hedonic Motivation (HM) having the maximum positive impact $(\mathrm{r}=0.708)$ and Facilitating Condition (FC) with minimum impact $(r=0.493)$. Among Precipitating Events $(\mathrm{PEV})$ and Behavioral Intention (BI), the later has higher correlation with Use Behavior (UB) $(r=0.843)$ [20].

\section{Moderation Analysis}

TABLE V

MODEL SUMMARY

(INTERACTION OF PEV AND BI, AND PEV ON UB) ${ }^{\mathrm{a}}$

\begin{tabular}{|l|l|l|l|l|}
\hline Model & $\mathrm{R}$ & $\mathrm{R}^{2}$ & $\begin{array}{l}\text { Adjusted } \\
\mathrm{R}^{2}\end{array}$ & $\begin{array}{l}\text { Std. Error } \\
\text { of the Estimate }\end{array}$ \\
\hline 1 & $.848^{\mathrm{a}}$ & 0.719 & 0.714 & 2.29216 \\
\hline
\end{tabular}

TABLE VI
MODEL (COEFFICIENTS AND PROBABILITY VALUE)

\begin{tabular}{|l|l|l|l|l|l|l|}
\hline & coeff & $\mathrm{se}$ & $\mathrm{t}$ & $\mathrm{p}$ & $\mathrm{LLCI}$ & $\mathrm{ULCI}$ \\
\hline constant & 13.7062 & 0.1954 & 70.1518 & 0.000 & 13.3203 & 14.092 \\
\hline $\begin{array}{l}\text { Behavioral } \\
\text { Intention (BI) }\end{array}$ & 0.768 & 0.0438 & 17.5174 & 0.000 & 0.6814 & 0.8546 \\
\hline $\begin{array}{l}\text { Precipitating } \\
\text { Event (PEV) }\end{array}$ & 0.0152 & 0.0625 & 0.2434 & 0.808 & -0.1082 & 0.1387 \\
\hline $\begin{array}{l}\text { Interaction (BI } \\
\text { X PEV) }\end{array}$ & 0.0203 & 0.0094 & 2.1674 & 0.0317 & 0.0018 & 0.0388 \\
\hline
\end{tabular}

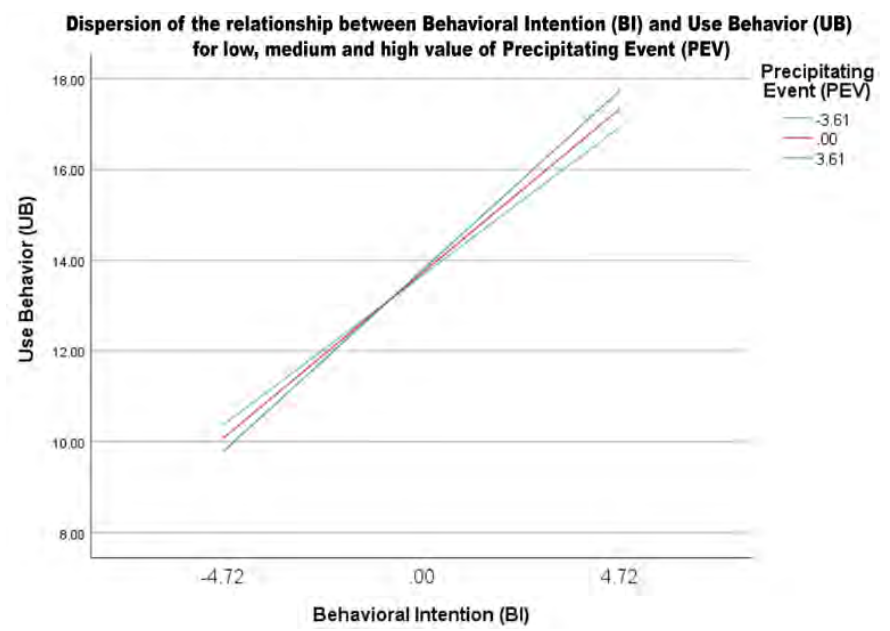

Fig. 2. Graph showing the dispersion of the relationship between Behavioral Intention (BI) and Use Behavior (UB), for low, medium and high value of moderator - Precipitating Event (PEV).

Figure 2 illustrates the moderation of Precipitating Event (PEV), which is COVID-19 pandemic, on the relationship between Behavioral Intention (student's intention to use online learning) and Use Behavior (student's adoption of online learning). For three levels of PEV value - low, medium, and high, the relationship is being moderated and hence, the lines representing the relationship intersect with each other. Had there been no moderation, the lines would have been parallel [17].

The probability value 'p' of interaction of moderator (PEV) and independent variable (BI) is significant on the dependent variable (UB) as the 'p' value is less than 0.05 . The graph plot also supports the value as the it shows non-parallel lines representing the effect of moderator PEV in its three level of values - low, medium and high. [17], [18].

The study hypotheses based on the research framework were tested and found supported (Table VII). Hedonic motivation has the highest correlation effect and Facilitating condition having the lowest effect on the students' behavioral intention to adopt online learning. It was also found that precipitating event (sudden crisis caused by COVID-19) effected and moderated students' behavioral intention towards their use behavior in case of online education in Bangladesh.

TABLE VII

HYPOTHESES TESTS 


\begin{tabular}{|l|l|}
\hline $\begin{array}{l}\text { H1.1: Performance expectancy has a } \\
\text { significant effect on the behavioral intention } \\
\text { of students to attend online classes. }\end{array}$ & Supported \\
\hline $\begin{array}{l}\text { H1.2: Effort expectancy has a significant } \\
\text { effect on the behavioral intention of students } \\
\text { to attend online classes. }\end{array}$ & Supported \\
\hline $\begin{array}{l}\text { H1.3: Social influence has a significant effect } \\
\text { on the behavioral intention of students to } \\
\text { attend online classes. }\end{array}$ & Supported \\
\hline $\begin{array}{l}\text { H1.4: Facilitating conditions have a } \\
\text { significant effect on the behavioral intention } \\
\text { of students to attend online classes. }\end{array}$ & Supported \\
\hline $\begin{array}{l}\text { H1.5: Hedonic motivation has a significant } \\
\text { effect on the behavioral intention of students } \\
\text { to attend online classes. }\end{array}$ & Supported \\
\hline $\begin{array}{l}\text { H1.6: Value has a significant effect on the } \\
\text { behavioral intention of students to attend } \\
\text { online classes. }\end{array}$ & Supported \\
\hline $\begin{array}{l}\text { H1.7: Precipitating Event moderated the } \\
\text { behavioral intention of students to attend } \\
\text { online classes. }\end{array}$ & Supported \\
\hline
\end{tabular}

\section{CONCLUSION}

A lesson learnt from COVID-19 pandemic by all sorts of organization certainly is to be flexible and agile, but yet resilient. For HEIs, these attributes also need to reflect among the students, teachers, and officials. Whether or not COVID 19 subsides in near future, our lifestyle is permanently altered. Turbulent times have a way of reordering the reality, but in the process, new opportunities and ideas also pave the way [3].

In this study, in alignment with UTAUT2's postulates, Performance Expectancy (PE), Effort Expectancy (EE), Social Influence (SI), Facilitating Conditions (FC), Value (VL), Hedonic Motivation (HM) were found to be significantly influential on student's intention to engage in online learning. Hedonic motivation; the excitement of adopting the new technology having the highest influence. The current COVID19 pandemic crisis also has a positive effect on the behavioral intention of the students in adopting the online learning technology.

In terms of incorporating entrepreneurial model and technology acceptance model, the research framework of this study itself is a novelty which can be used in similar technology acceptance research in other domains, particularly during this ongoing disruptive time of COVID-19 pandemic. The study has revealed some previously unexplored insights about private university students of Bangladesh- their perception towards online learning.

This study was based on the students who successfully participated in the online class in a homogenous environment. Unfortunately, that might not have the case for many universities of the country even the ones who managed to take online classes during this coronavirus pandemic. Hence, it may not be possible to generalize the findings for the HEIs of Bangladesh. Even though the most widely popular research framework [21] was used to assess the adoption of technology; but the current pandemic situation is also completely unprecedented. This is also proven to be the novelty of this article. This study definitely establishes a guideline for future researches and decision makers to assess technology adoption and impact of unexpected uncertain events on users' behavioral intention.

\section{REFERENCES}

[1] Mohiuddin Alamgir (2020, May 9). Online Classes Amid Shutdown: A distant reality, still for many. The Daily Star. https://www.thedailystar.net/frontpage/news/online-classesamid-shutdown-distant-reality-still-many-1900918. (Accessed 31 July 2021)

[2] Priyo, A. K. K. and Hazra, U. (2021, July 18). Digital divide in online class during Covid-19 pandemic. The Financial Express. https://thefinancialexpress.com.bd/views/digitaldivide-in-online-class-during-covid-19-pandemic1626620177 (Accessed on July 31, 2021)

[3] Lamagna, C. Z. (2020, Apr 9). A PARADIGM SHIFT: The Case of AIUB. The Daily Star. https://www.thedailystar.net/shout/news/paradigm-shift-thecase-aiub-1891033. (Accessed 31 July 2021)

[4] Fakir, Adnan M. S. (2020, May 8). Shifting universities to non-physical platforms- Collaborative efforts will be the way forward, The Daily Star. https://www.thedailystar.net/opinion/news/shiftinguniversities-non-physical-platforms-1900390. (Accessed on July 31, 2021)

[5] Dakduk, S., Santalla-Banderali, Z., \& van der Woude, D. (2018). Acceptance of blended learning in executive education. SAGE Open, 8(3), 2158244018800647.

[6] Aucejo, E. M., French, J., Araya, M. P. U., \& Zafar, B. (2020). The impact of COVID-19 on student experiences and expectations: Evidence from a survey. Journal of public economics, 191, 104271.

[7] Putri, R. E., \& Oktavia, R. (2020). Evaluation of the Effectiveness Online Class on Fundamental Biophysics Class During COVID 19 Quarantine. SEMESTA: Journal of Science Education and Teaching, 3(1), 65-70.

[8] Tabassum, M., Mannan, S. E., Parvej, M. I., \& Ahmed, F. (2021). Online Education during COVID-19 in Bangladesh: University Teachers' Perspective. Aquademia, 5(1), ep21005.

[9] Al-Zaman, M. S. (2020). Digitalization and transformation of teaching and learning in Bangladesh. In Challenges and Opportunities in Global Approaches to Education (pp. 5677). IGI Global.

[10] Lin, Z., \& Theingi, H. (2019). Extended utaut2 model on factors influencing of mobile commerce acceptance in Yangon, Myanmar. AU-GSB e-journal, 12(2), 3-18.

[11] Venkatesh, V., Thong, J.Y.L. and Xu, X. (2012). Consumer acceptance and use of information technology: extending the unified theory of acceptance and use of technology. MIS Quarterly, Vol. 36 No. 1, 157-178.

[12] Venkatesh, V., Thong, J. Y., \& Xu, X. (2016). Unified theory of acceptance and use of technology: A synthesis and the road ahead. Journal of the association for Information Systems, 17(5), 328-376.

[13] Moghavvemi, S.; Mohd Salleh, N.A.; Zhao, W. and Mattila, M.M. (2012). The Entrepreneur's Perception of Information Technology Adoption: An Empirical Analysis of the Role of Precipitating Events on Usage Behavior. Innovation: Management, Policy \& Practice. 14(3): 220-235.

[14] Krueger, N. F., Schulte, W. D., \& Stamp, J. (2008). Beyond intent: antecedents of resilience \& precipitating events for 
social entrepreneurial intentions and... action. Action (January 25, 2008)

[15] Krueger, N. F. (2017). Entrepreneurial intentions are dead: Long live entrepreneurial intentions. In Revisiting the entrepreneurial mind (pp. 13-34). Springer, Cham.

[16] Al-Okaily, M., Alqudah, H., Matar, A., Lutfi, A. A., \& Taamneh, A. (2020). Impact of Covid-19 pandemic on acceptance of elearning system in Jordan: A case of transforming the traditional education systems. Humanities and social Sciences Review, 6(4), 840-851.

[17] Hayes, A. F., \& Rockwood, N. J. (2017). Regression-based statistical mediation and moderation analysis in clinical research: Observations, recommendations, and implementation. Behaviour Research and Therapy, 98, 3957.

[18] Canniatti Ponchio, M., \& Samartini Correio, A. (2018). The simple moderation model and its use in business research. Internext: Revista Electrônica de Negócios Internacionais da ESPM, 13(1).

[19] Memon, M. A., Ting, H., Cheah, J. H., Thurasamy, R., Chuah, F., \& Cham, T. H. (2020). Sample size for survey research: review and recommendations. Journal of Applied Structural Equation Modeling, 4(2), 1-20.

[20] Sürücü, L., \& Maslakçi, A. (2020). Validity and Reliability In Quantitative Research. Business \& Management Studies: An International Journal, 8(3), 2694-2726.

[21] Salloum, S. A., \& Shaalan, K. (2018, September). Factors affecting students' acceptance of e-learning system in higher education using UTAUT and structural equation modeling approaches. In International Conference on Advanced Intelligent Systems and Informatics (pp. 469-480). Springer, Cham.

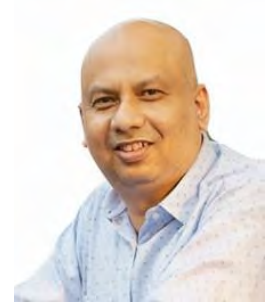

By birth a Bangladeshi, Manzur H Khan is currently pursuing his $\mathrm{PhD}$ at the School of Quantitative Sciences in the Universiti Utara Malaysia (UUM). He completed his Bachelor and Master of Science Degree in physics from the University of Dhaka in 1999. In 2001, he completed his Master of Science degree in business information technology from the University of Westminster, London, UK.

He joined the American International University-Bangladesh (AIUB) as a faculty member of the Department of Computer Science in 2002 and has been teaching numerous undergraduate and postgraduate courses since then. His area of specialization is Management Information Systems with emphasis on System Analysis and Design, Information System Management, Software Engineering, Database and Human Computer Interaction. As additional administrative responsibilities he was appointed as the Coordinator of the Office of Student Affairs in 2005 and later promoted as the Director in 2010.

Mr. Manzur has completed Oracle Database Administrator Certification course in 2004, Sun Java Instructor certification in 2006. Mr. Manzur was a member of the inaugural program of the Education USA Leadership Institute and is an International Exchange Alumni of the Department of State, USA. In 2012, Mr. Manzur worked as an Exchange Faculty under LinnaeusPalme Exchange Program at the Department of Business and Economics Study, University of Gavle, Sweden.

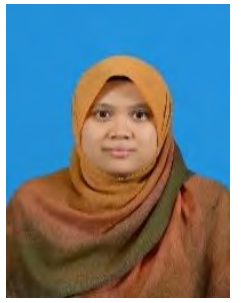

NurAkmal Ahmad Mustaffa is a Senior Lecturer at the Department of Decision Science in the School of Quantitative Sciences, Universiti Utara Malaysia. Her area of specialization and research interests include Deterministic and Stochastic Difference, Supply Chain Management, Markov Decision Process, Discrete Event, Disruption Risk, Inventory Management and Control.

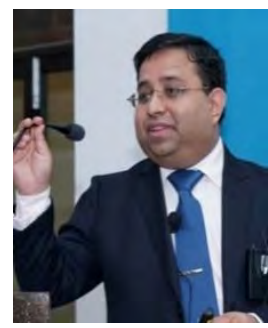

Prof. Dr. Md. Mamun Habib is a Professor at School of Business \& Entrepreneurship (SBE), Independent University, Bangladesh (IUB). In addition, Dr. Habib is the Visiting Scientist of University of Texas Arlington, USA. Prior to that, he was Associate Professor at BRAC Business School, BRAC University, Bangladesh; Asia Graduate School of Business (AGSB), UNITAR International University, Malaysia; Dept. of Operations Research/Decision Sciences, Universiti Utara Malaysia (UUM), Malaysia and Dept. of Operations Management, American International UniversityBangladesh (AIUB).

He has more than 19 years' experience in the field of teaching as well as in training, workshops, consultancy and research. At present, he is supervising some Ph.D. students at locally and internationally. As a researcher, Dr. Habib published about $160+$ research papers, including Conference Proceedings, Journal articles, and book chapters/books. He serves as the Editor-inChief/Lead Guest Editor/Editor/Editorial Board Member/Reviewer of more than 20 journals, particularly Elsevier (Scopus) and Thomson Reuters (Web of Science) Indexed Journals. In addition, he delivers lecture as Keynote Speaker at $65+$ international conferences in the globe.

His core research areas are supply chain management, production \& operations management, operations research, research methodology. Finally, Dr. Habib is an active member of different professional organizations, including IEEE (Senior Member), IEOM (President, SCM Technical Division), IETI (Senior Member and Board of Director), IRED (Fellow), GRDS (Vice-President), IEB, AIMS, INFOMS, just to name a few. He is involved with QS World University Ranking and Times Higher Education Ranking as an academician.

Appendix A: Demography
\begin{tabular}{|l|l|l|l|l|}
\hline Item & Category & $\begin{array}{l}\text { Total } \\
\%\end{array}$ & $\begin{array}{l}\text { Male } \\
\%\end{array}$ & $\begin{array}{l}\text { Female } \\
\%\end{array}$ \\
\hline \multirow{3}{*}{$\begin{array}{l}\text { Monthly } \\
\text { Family }\end{array}$} & $25 \mathrm{~K}<$ & 17.90 & 16.54 & 22.86 \\
\cline { 2 - 5 } & $25 \mathrm{~K}-50 \mathrm{~K}$ & 37.65 & 39.37 & 31.43 \\
\cline { 2 - 5 } & $50 \mathrm{~K}-75 \mathrm{~K}$ & 24.69 & 23.62 & 28.57 \\
\cline { 2 - 5 } & $75 \mathrm{~K}-100 \mathrm{~K}$ & 11.11 & 11.81 & 8.57 \\
\cline { 2 - 5 } & $>100 \mathrm{~K}$ & 8.64 & 8.66 & 8.57 \\
\hline \multirow{3}{*}{$\begin{array}{l}\text { Everyday } \\
\text { Unternet }\end{array}$} & 1 hour $<$ & 1.85 & 2.36 & 0.00 \\
\cline { 2 - 5 } & $1-2$ hour & 10.49 & 10.24 & 11.43 \\
\cline { 2 - 5 } & $3-5$ hour & 40.12 & 35.43 & 57.14 \\
\cline { 2 - 5 } & $5-8$ hour & 26.54 & 27.56 & 22.86 \\
\cline { 2 - 5 } & $>8$ hour & 20.99 & 24.41 & 8.57 \\
\hline
\end{tabular}




\begin{tabular}{|c|c|c|c|c|}
\hline \multirow{5}{*}{$\begin{array}{l}\text { Purpose of } \\
\text { Using } \\
\text { Internet } \\
\text { (Priority) }\end{array}$} & $\begin{array}{l}\text { Entertainmen } \\
\mathrm{t}\end{array}$ & 36.42 & 37.80 & 31.43 \\
\hline & Education & 43.83 & 42.52 & 48.57 \\
\hline & Profession & 11.11 & 11.02 & 11.43 \\
\hline & News & 5.56 & 5.51 & 5.71 \\
\hline & Others & 3.09 & 3.15 & 2.86 \\
\hline \multirow{5}{*}{$\begin{array}{l}\text { Usage of } \\
\text { Internet } \\
\text { for Social } \\
\text { Media } \\
\text { every day }\end{array}$} & 1 hour $<$ & 20.99 & 23.62 & 11.43 \\
\hline & $1-2$ hour & 33.33 & 33.07 & 34.29 \\
\hline & $3-5$ hour & 37.65 & 34.65 & 48.57 \\
\hline & $5-8$ hour & 4.94 & 4.72 & 5.71 \\
\hline & $>8$ hour & 3.09 & 3.94 & 0.00 \\
\hline \multirow{3}{*}{$\begin{array}{l}\text { Device } \\
\text { used } \\
\text { for online } \\
\text { access }\end{array}$} & Desktop & 11.73 & 14.17 & 2.86 \\
\hline & Laptop & 58.64 & 58.27 & 60.00 \\
\hline & $\begin{array}{l}\text { Mobile } \\
\text { Phone }\end{array}$ & 29.63 & 27.56 & 37.14 \\
\hline \multirow{5}{*}{$\begin{array}{l}\text { Operating } \\
\text { System } \\
\text { used for } \\
\text { online } \\
\text { access }\end{array}$} & Windows & 68.52 & 70.87 & 60.00 \\
\hline & Android & 25.93 & 24.41 & 31.43 \\
\hline & iOS & 2.47 & 1.57 & 5.71 \\
\hline & Mac OS & 1.23 & 0.79 & 2.86 \\
\hline & Others & 1.85 & 2.36 & 0.00 \\
\hline \multirow{3}{*}{$\begin{array}{l}\text { Type of } \\
\text { internet } \\
\text { connectivit } \\
\text { y }\end{array}$} & $\begin{array}{l}\text { Broadband } \\
\text { (ISP) }\end{array}$ & 66.67 & 70.08 & 54.29 \\
\hline & Mobile data & 32.10 & 29.13 & 42.86 \\
\hline & Others & 1.23 & 0.79 & 2.86 \\
\hline \multirow{6}{*}{$\begin{array}{l}\text { Type of } \\
\text { internet } \\
\text { speed }\end{array}$} & $1 \mathrm{Mbps}<$ & 25.31 & 27.56 & 17.14 \\
\hline & $1-10 \mathrm{Mbps}$ & 51.23 & 55.12 & 37.14 \\
\hline & $11-20 \mathrm{Mbps}$ & 6.17 & 6.30 & 5.71 \\
\hline & $20-30 \mathrm{Mbps}$ & 3.70 & 3.94 & 2.86 \\
\hline & $>30 \mathrm{Mbps}$ & 1.23 & 0.79 & 2.86 \\
\hline & Not sure & 12.35 & 6.30 & 34.29 \\
\hline \multirow{3}{*}{$\begin{array}{l}\text { Location } \\
\text { from } \\
\text { where } \\
\text { accessing } \\
\text { online class }\end{array}$} & City (Urban) & 61.73 & 61.42 & 62.86 \\
\hline & Suburban & 16.05 & 17.32 & 11.43 \\
\hline & Rural & 22.22 & 21.26 & 25.71 \\
\hline \multirow{2}{*}{$\begin{array}{l}\text { Previous } \\
\text { Experience } \\
\text { of Online } \\
\text { Learning }\end{array}$} & Yes & 45.06 & 45.67 & 42.86 \\
\hline & No & 54.94 & 54.33 & 57.14 \\
\hline \multirow{5}{*}{$\begin{array}{l}\text { Time spent } \\
\text { to get used } \\
\text { to } \\
\text { with } \\
\text { Microsoft } \\
\text { Teams } \\
\end{array}$} & 1 Hour $<$ & 27.16 & 29.13 & 20.00 \\
\hline & $1-2$ Hour & 39.51 & 39.37 & 40.00 \\
\hline & $2-5$ Hour & 12.35 & 11.81 & 14.29 \\
\hline & $5-10$ Hour & 2.47 & 3.15 & 0.00 \\
\hline & Not sure & 18.52 & 16.54 & 25.71 \\
\hline
\end{tabular}

\begin{tabular}{|c|c|c|}
\hline Effort Expectancy (EE) & \multirow{3}{*}{$\begin{array}{l}\text { EE1 } \\
\text { EE2 }\end{array}$} & \multirow{4}{*}[11]{} \\
\hline 5. ONLINE learning is easy to use & & \\
\hline $\begin{array}{l}\text { 6. Adopting how to use ONLINE } \\
\text { learning features is easy for me }\end{array}$ & & \\
\hline $\begin{array}{l}\text { 7. My interaction with ONLINE } \\
\text { learning is clear and } \\
\text { understandable }\end{array}$ & EE3 & \\
\hline \multicolumn{3}{|l|}{ Social Influence (SI) } \\
\hline $\begin{array}{l}\text { 8. My peers who influence my } \\
\text { behavior think that I should } \\
\text { attend ONLINE learning }\end{array}$ & SI1 & \multirow[t]{4}{*}{ [11] } \\
\hline $\begin{array}{l}\text { 9. My friends who are important to } \\
\text { me think that I should attend } \\
\text { ONLINE learning }\end{array}$ & SI2 & \\
\hline $\begin{array}{l}\text { 10. My instructors whose opinions } \\
\text { that I value prefer that I should } \\
\text { attend ONLINE learning }\end{array}$ & SI3 & \\
\hline $\begin{array}{l}\text { 11. Overall, the university may } \\
\text { support ONLINE learning }\end{array}$ & SI4 & \\
\hline \multicolumn{3}{|l|}{ Facilitating Conditions (FC) } \\
\hline $\begin{array}{l}\text { 12. I have required resources to } \\
\text { attend ONLINE learning }\end{array}$ & FC1 & \multirow[t]{3}{*}{ [11] } \\
\hline $\begin{array}{l}\text { 13. I have knowledge to attend } \\
\text { ONLINE learning }\end{array}$ & $\mathrm{FC} 2$ & \\
\hline $\begin{array}{l}\text { 14. I can get help from others when } \\
\text { difficulties arise in ONLINE } \\
\text { learning }\end{array}$ & FC3 & \\
\hline \multicolumn{3}{|l|}{ Value (VL) } \\
\hline $\begin{array}{l}\text { 15. ONLINE learning is worth more } \\
\text { than the time and effort given to } \\
\text { it }\end{array}$ & VL1 & \multirow[t]{3}{*}{ [11] } \\
\hline $\begin{array}{l}\text { 16. In less time, ONLINE learning } \\
\text { allows me to quickly and easily } \\
\text { share my knowledge with others } \\
\text { (e.g. chat session, forums, blogs, } \\
\text { etc.) }\end{array}$ & VL2 & \\
\hline $\begin{array}{l}\text { 17. ONLINE learning gives me the } \\
\text { opportunity to increase my } \\
\text { knowledge and to control my } \\
\text { success (e.g., via quizzes and } \\
\text { assignments/assessments, etc.) }\end{array}$ & VL3 & \\
\hline \multicolumn{3}{|l|}{ Hedonic Motivation (HM) } \\
\hline $\begin{array}{l}\text { 18. I feel fun attending ONLINE } \\
\text { learning }\end{array}$ & HM1 & \multirow[t]{3}{*}{ [11] } \\
\hline $\begin{array}{l}\text { 19. I enjoy attending ONLINE } \\
\text { learning }\end{array}$ & HM2 & \\
\hline $\begin{array}{l}\text { 20. Attending ONLINE learning is } \\
\text { very fulfilling }\end{array}$ & HM3 & \\
\hline \multicolumn{3}{|l|}{ Precipitating events (PEV) } \\
\hline $\begin{array}{l}\text { 21. Sudden changes in my work } \\
\text { situation influenced my decision } \\
\text { in joining Online learning }\end{array}$ & PEV1 & \multirow[t]{3}{*}{ [13] } \\
\hline $\begin{array}{l}\text { 22. Sudden change in my work } \\
\text { environment influenced my } \\
\text { decision in attending Online } \\
\text { learning }\end{array}$ & PEV2 & \\
\hline $\begin{array}{l}\text { 23. My decision to change my work } \\
\text { situation due to recent }\end{array}$ & PEV3 & \\
\hline
\end{tabular}

Appendix B: Variables and Items
\begin{tabular}{|l|l|l|l|}
\hline Variables and Items & Code & References \\
\hline Performance Expectancy (PE) & & \\
\hline 1. & $\begin{array}{l}\text { I find ONLINE learning useful } \\
\text { for my studies }\end{array}$ & PE1 & {$[11]$} \\
\hline 2. & $\begin{array}{l}\text { ONLINE learning allows me to } \\
\text { accomplish class activities more } \\
\text { quickly }\end{array}$ & PE2 & \\
\cline { 1 - 2 } 3. & $\begin{array}{l}\text { ONLINE learning increases my } \\
\text { learning productivity }\end{array}$ & PE3 & \\
\cline { 1 - 2 } 4. & $\begin{array}{l}\text { ONLINE learning increases } \\
\text { chances of receiving better grades }\end{array}$ & PE 4 & \\
\hline
\end{tabular}




\begin{tabular}{|c|c|c|}
\hline $\begin{array}{lcr}\text { opportunity } & \text { or lack of } \\
\text { opportunity } & \text { influenced } & \text { my } \\
\text { decision in } & \text { attending Online } \\
\text { learning } & & \end{array}$ & & \\
\hline \multicolumn{3}{|l|}{ Behavioral Intention (BI) } \\
\hline $\begin{array}{l}\text { 24. I intend to continue using } \\
\text { ONLINE learning }\end{array}$ & BI1 & \multirow[t]{3}{*}[11]{} \\
\hline $\begin{array}{l}\text { 25. For my studies, I would use } \\
\text { ONLINE learning }\end{array}$ & $\mathrm{BI} 2$ & \\
\hline $\begin{array}{l}\text { 26. I will continue to use ONLINE } \\
\text { learning on a regular basis }\end{array}$ & $\mathrm{BI} 3$ & \\
\hline \multicolumn{3}{|l|}{ Use Behavior (UB) } \\
\hline $\begin{array}{l}\text { 27. I use ONLINE learning for my } \\
\text { studies }\end{array}$ & UB1 & \multirow[t]{3}{*}[11]{} \\
\hline $\begin{array}{l}\text { 28. I use many features of ONLINE } \\
\text { learning (discussion, quiz, chat, } \\
\text { tools, etc.) }\end{array}$ & UB1 & \\
\hline $\begin{array}{l}\text { 29. I depend on ONLINE learning } \\
\text { (16) }\end{array}$ & UB3 & \\
\hline
\end{tabular}

